\title{
Peningkatan Kemampuan Membaca Permulaan Melalui Permainan Bahasa Pada Siswa Kelas 1 SDN Mumbul Sari
}

\author{
${ }^{1}$ Sukarto, ${ }^{2}$ Emiliana, ${ }^{3}$ Raden Sumiadi \\ STKIP HAMZAR, PGSD \\ Email: kartosu731@gmail.com
}

\begin{abstract}
Abstrak
Penelitian ini bertujuan untuk meningkatkan kemampuan membaca permulaan pada siswa kelas 1 di SDN Mumbul Sari. Penelitian didesain dengan menggunakan desain penelitian tindakan kelas yang terdiri dari dua siklus. Pada masing-masing siklus terdiri dari 4 tahapan yaitu, tahap perencanaan, tahap pelaksanaan tindakan, tahap observasi, dan tahap refleksi. Tahap perencanaan merupakan tahapan dalam mengembangkan perangkat pembelajaran yang dapat mendukung pembelajaran di kelas seperti menyusun RPP, menentukan metode yang tepat, mengembangkan media dan menyusun instrumen penilaian. Tahap pelaksanaan adalah tahapan peneliti dan menerapakan RPP, media, dan instrumen penilaian yang telah dikembangkan. Tahap observasi merupakan tahap dimana peneliti melakukan proses pengamatan terhadap pelaksanaan pembelajaran, objek pengamatan adalah guru dan siswa. Tahap refleksi adalah tahapan peneliti dalam mengevaluasi kekurangan dalam proses pembelajaran sebelumnya sebagai bahan perbaikan dalam mengelola pembelajaran pada tahap berikutnya. Dalam penelitian ini, instrumen yang digunakan untuk mengumpulkan data adalah tes hasil belajar, lembar observasi, dokumentasi dan wawancara, selanjutnya data yang diperoleh dianalisis dengan rumus ketuntasan individu dan klasikal. Berdasarkan hasil analisis data menunjukkan bahwa hasil kemampuan membaca permulaan siswa sebagai berikut; siklus I prosentase kemampuan pengenalan bentuk huruf $(60,16 \%)$, pengenalan unsur-unsur bahasa $(61,72 \%)$, dan pengenalan pola ejaan $(70,31 \%)$. Sedangkan pada siklus II prosentase kemampuan pengenalan bentuk huruf $(90,63 \%)$, pengenalan unsur-unsur bahasa $(87,50 \%)$, dan kemampuan pengenalan pola ejaan $(87,50 \%)$. Dalam penelitian ini terdapat peningkatan kemampuan bahasa permulaan siswa kelas 1 SDN Mumbul Sari.
\end{abstract}

\section{Kata kunci: Kemampuan membaca dan permainan bahasa}

\section{PENDAHULUAN}

Pendidikan dasar pada sekolah dasar merupakan momentum awal bagi anak untuk meningkatkan kemampuan dirinya. Dari bangku sekolah dasarlah mereka mendapatkan imunitas belajar yang kemudian menjadi kebiasaan- kebiasaan yang akan mereka lakukan di kemudian hari. Sehingga peran seorang guru sangatklah penting untuk dapat menanmkan kebiasaan baik bagi siswanya, bagaiman mereka dituntut memiliki kompetensi-kompetensi yang kemudian dapat meningkatkan kemampuan istimewa (Susanto, 2012:241).

Salah satu pelajaran yang dapat mewujudkan kemampuan istimewa peserta didik adalah pembelajaran bahasa Indonesia, mata pelajaran ini tidak hanya menyangkut keterampilan berbahasa, yaitu menyimak, berbicara tetapi juga menyangkut kemampuan membaca dan menulis. Kemampuan berbahasa bagi siswa Sekolah Dasar (SD) sangat diperlukan dalam proses belajar dan pembelajaran di kelas.

Dengan demikian guru sebagai fasilitator, mediator dan pembimbing dalam proses belajar mengajar sudah semestinya untuk mampu mengelola strategi pembelajaran dengan tepat. Melalui penguasaan metode yang baik akan menjadi salah satu triger bagi siswa untuk melakukan proses belajar dan pembelajaran yang menyenangkan pada semua mata pelajaran khususnya pelajaran bahasa Inodnesia. Strategi pengajaran efektif dan menyenangkan, guru akan menjadi stimulus bagi siswa dalam menumbuhkan kemampuan membaca pada setiap pembelajaran baik pelajaran bahasa Indonesia 
maupun mata pelajaran yang lain.

Permainan merupakan alat bagi anak untuk menjelajahi dunianya, dari yang tidak dikenali sampai pada yang diketahui, dan dari yang tidak dapat diperbuatnya sampai mampu melakukannya. Bermain bagi anak memiliki nilai dan ciri yang penting dalam kemajuan perkembangan kehidupan seharihari. Pada permulaan setiap pengalaman bermain memiliki resiko. Ada resiko bagi anak untuk belajar misalnya naik sepeda sendiri, belajar meloncat. Unsur lain adalah pengulangan. Anak mengkonsolidasikan ketrampilannya yang harus diwujudkannya dalam berbagai permainan dengan nuansa yang berbeda

Berdasarkan observasi yang dilakukan, 16 April 2019 sekolah ini terlihat masih melakukan pembelajaran dengan sistim ceramah tanpa melibatkan siswa secara dominan, disamping itu dari KKM sekolah yang sudah ditentukan sebanyak 65 ditemukan lebih banyak siswa yang belum mampu memenuhi KKM pada saat ujian berlangsung khususnya pada pelajaran bahasa Indonesia. Kemudian berdasarkan fakta yang ada, masih banyak guru yang belum memiliki kemampuan memadai dalam menopang siswa menciptakan kebiasaan membaca. Berdasarkan uraian masalah tersebut sehingga perlu diadakan penelitian dengan judul peningkatan kemampuan membaca permulaan melalui permainan bahasa.

\section{METODE}

Penelitian ini didesain sebagai penelitian tindakan kelas yang terdiri dari 2 siklus dan 4 tahapan pada masing-masing siklus. Data berupa kemampuan membaca permulaan siswa pada masing-masing siklus selanjutnya di analisis dengan mengguanakan rumus ketuntasan individu dan rumus ketuntasan klasikal.

Rumus ketuntasan Individu

\begin{tabular}{|c|}
\hline Nilai $=\frac{\text { Skor yang diperoleh siswa }}{\text { skor maksimal }} \times 100 \%$ \\
Rumus Ketuntasan Klasikal \\
Nilai $=\frac{\text { jumlah siswa yang tuntas }}{\text { jumlah siswa keseluruhan }} \times 100 \%$
\end{tabular}

Jurnal Ilmiah Mandala Education

\section{HASIL DAN PEMBAHASAN}

Hasil dan pembahasan dalam penelitian ini disajikan dalam bentuk tabel, grafik dan deskripsi hasil.

Tabel1.1 Kemampuan Membaca Permulaan siklus 1

\begin{tabular}{|c|l|c|}
\hline No & \multicolumn{1}{|c|}{ Indikator } & Persentase \\
\hline 1 & Pengenalan Bentuk Huruf & $60,16 \%$ \\
\hline 2 & $\begin{array}{l}\text { Pengenalan Unsur-unsur } \\
\text { Bahasa }\end{array}$ & $61,72 \%$ \\
\hline 3 & Pengenalan Pola Ejaan & $70,31 \%$ \\
\hline
\end{tabular}

Tabel 1.2 kemampuan membaca permulaan siklus 2

\begin{tabular}{|c|l|c|}
\hline No & \multicolumn{1}{|c|}{ Indikator } & Persentase \\
\hline 1 & $\begin{array}{l}\text { Pengenalan Bentuk } \\
\text { Huruf }\end{array}$ & $90,63 \%$ \\
\hline 2 & $\begin{array}{l}\text { Pengenalan Unsur- } \\
\text { Unsur Bahasa }\end{array}$ & $87,50 \%$ \\
\hline 3 & Pengenalan Pola Ejaan & $93,75 \%$ \\
\hline
\end{tabular}

\section{KESIMPULAN}

Berdasarkan hasil penelitian dan pembahasan dapat disimpulkan bahwa permainan bahasa dapat meningkatkan kemampuan membaca permualaan siswa kelas 1 SDN mumbul sari.

\section{DAFTAR PUSTAKA}

Abbas, Saleh. (2006). Pembelajaran Bahasa Indonesia yang Efektif di Sekolah Dasar. Jakarta: Depdiknas.

Abdurrahman, Mulyono. 2002. Pendidikan Bagi Anak Berkesulitan Belajar.Jakarta: Rineka Cipta.

Agus Suyatna.2008 Model Model Pembelajara paikem.Bandar Lampung

Andi Thahir. 2012. Psikologi Belajar Pengantar Dalam Memahami Psikologi Belajar. Yagyakarta: Pustaka Pelajar

Arikunto, Suharsimi, 2013. Prosedur Penelitian Suatu Pendekatan Praktik. Jakarta: Rineka Cipta 
Djauhar, M. Siddiq. dkk. (2008). Pengembangan Bahan Pembelajaran SD. Jakarta: Direktorat Jenderal Pendidikan Tinggi.

Djuanda, Dadan. (2006). Pembelajaran Bahasa Indonesia yang Komunikatif dan Menyenangkan. Jakarta: Departemen Pendidikan Nasional.

Rahim, Farida. 2005. Pengajaran Membaca di Sekolah Dasar. Bandung : Bumi Aksara

Susanto, Ahmad. 2012. Teori Belajar dan Pembelajaran di Sekolah Dasar. Jakarta: Kencana Pranada Media

Suyatno. 2005. Menjelajah Pembelajaran Inovatif. Bandung: Masmedia Buana Pustaka

Takdiratun, Musfiroh, 2009. Mengembangkan Baca Tulis Anak. Yogyakarta : Grasindo 